\title{
Forensic Odontology -A misfit or misunderstood
}

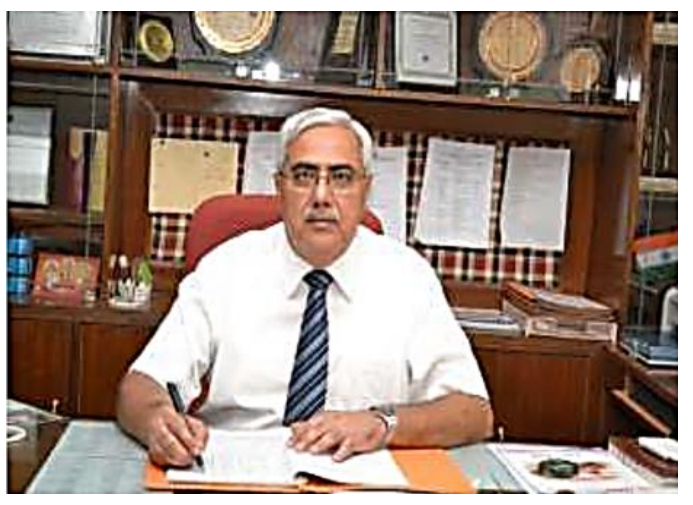

Prof. (Dr.) Vinod Sachdev

Director-PG Studies, I.T.S Centre for Dental Studies and Research, Muradnagar

Editor-in-chief

\section{Dear Readers!}

Greetings and welcome to the latest edition!

Forensic odontology is a speciality of dentistry which deals with dynamic overlaps of dentistry with legal and forensic medicine. Keiser -Neilson defined forensic dentistry that in the interest of justice deals with the proper handling and examination of dental evidence and the proper evaluation and presentation of dental findings. ${ }^{1}$ This is one of the most interesting field yet often most misunderstood field of all the areas of dental profession.

History of forensic odontology frequently, takes us back into Ancient Roman era of $49 \mathrm{AD}$ where the identification of Lollia Paulina was done by Agrippina by visual recognition of Lollia's distinctive teeth. In history, there are several other cases which show us the glimpse of forensic science at work along with the hard work of different dentists such as Dr Paul Revere, Dr Parkman but the honour of being called father of forensic odontology is bestowed upon Oscar Amoedo. Oscar Amoedo a Cuban dentist working in Paris at the time of Bazar de la Charite fire which happened on May 4, 1897 in Rue Jean-Goujon. He reported in his textbook L' Art Dentaire en Medecine Legale many aspects of the use of teeth for legal purposes, the outcomes of the work done by other dentist after the fire. $^{1,2,2}$ After the Bazar de la Charite fire many authors published case studies on the use of odontology in both single and multiple fatality incidents which indicated an awareness of the value of the dentition in the identification of the deceased. These cases provide evidence of increased formalisation and consistency of the methods of victim recovery and scientific identification practices. However, the use of forensic odontology was still sporadic in most countries even until the 1960's. ${ }^{3}$

In India the first forensic identification was done by Gahadavala dynasty, (1191) a great monarchy which was destroyed by Muhammad's army. Raja Jayachandra Rathore of Kanauji died in battlefield and was identified by his false anterior teeth. ${ }^{4}$ Even though, with such an early start in the field of forensic odontology, the field is still in its nascent stages in our country. In India, 313 dental institutes with nearly 1.3 lakh students graduating as dentists and workforce of more than 2.7 lakhs, ${ }^{5}$ but yet no dental institute is yet offering a council-recognised master's program for forensic odontology. Several organisations such IAFO- Indian Association of Forensic Odontology and Indian Dental Association (IDA) conducts certificate courses and fellowship programs in forensic odontology throughout the country, while Indian Universities recognised and affiliated by University Grant Commission (UGC) $)^{6,7,8}$ i.e. Gujarat Forensic Sciences University $(\mathrm{GFSU})^{8}$ has 2-year master's programme in Masters in Forensic Odontology. And, foreign trained forensic odontologists who are mostly graduating from countries such as Belgium, Australia and UK who are offering their services to academic and judico-legal field, trying to establish the forensic odontology in India.

Currently the subject of forensic odontology is not introduced as a separate subject in undergraduate curriculum. But, under revised bachelor of dental surgery (BDS) course, as part of 2007 regulation, forensic odontology is added into the syllabus with both lecture and practical sessions, first part of which is taken as part of Department of Oral Pathology in first and third year curriculum, while the clinical aspect of this branch is taken by Department of Oral Medicine in Fourth year BDS curriculum. ${ }^{9}$ Recognition and qualifying are a major step in establishing any field, unfortunately the master's or diploma courses in India and abroad are not recognised by the governing body of dentistry in India. Even though this is the scenario on one side, on the other hand, some of the dental institutes of the country are establishing a separate forensic odontology branch or with the support of oral pathology and 
oral medicine departments. The forensic odontologists trained in India and abroad are recruited as faculty in such departments while others are part of identification and profiling team in medical colleges for unidentified human remains where they also impart services in the other areas of forensic odontology.

A multispectral approach of forensic odontology along with the forensic medicine department, forensic science laboratories (FSLs), forensic anthropology department and legal department is mandatory for the successful evolution of forensic odontology in our country. As this branch of dentistry has the potential to act as bridge between the Ministry of Health, Ministry of Home Affairs in every state and central governing bodies allowing interaction and work flow between the departments of disaster management, military, foreign and judicial affairs. ${ }^{10}$ I strongly recommend one chance should be given to this field of dentistry before we make decision whether forensic odontology is a misfit or misunderstood branch of dentistry, and this would allow us to unveil what forensic odontology has in store.

I am very thankful to our readers for encouraging and showing faith in us. This has made us pursue success with our every upcoming subscription. I wish you all magnificent reading experience. Please feel free to reach out to us as "your feedback is very significant for our growth".

\section{References}

1. Catherine Adams. Forensic Odontology: An Essential Guide. First Edition. John Wiley \& sons, Ltd; 2014.

2. Amoedo O. El incendio del Bazar de la Caridad [Fire on the Charity Bazaar]. Rev Museo Fac Odontol B Aires 1998;13(6):16-20.

3. Taylor J. A brief history of forensic odontology and disaster victim identification practices in Australia. J Forensic Odontostomatol 2009;27(2):64-74.

4. DinkarAD. Forensic odontology: Trends in India. $J$ Forensic Dent Sci 2014;6:1-2.

5. Jain H, Agarwal A. current scenario and crisis facing dental college graduates in India. J Clin Diagn Res 2012;6(1):1-4.

6. Pillai J P, Chokkalingam T S, Aasaithambi B, Nuzzolese E. Establishment of the Forensic odontology department: A proposed model for the basic infrastructure and forensic odontology kit. J Forensic Dent Sci 2019;11(2):64-72.

7. Available from: https://www.jssuni.edu.in/JSSWeb/UDDData/Docs/DentalMSc-Forensic -OdontologySylbs.pdf.

8. Available from: http://www.gfsu.edu.in/institute-offorensic-science/programs-ifs/.

9. Available from: http://www.dciindia.gov.in/Rule_Regulation/Revised_BDS_ Course_Regulation_2007.pdf.

10. Nuzzolese E, Di Vella G. Future project concerning mass disaster management: A forensic odontology prospectus. Int Dent J 2007;57:261-6.

How to cite the article: Sachdev V. Forensic odontology A misfit or misunderstood. $J$ Dent Specialities $2019 ; 7(2): 64-5$. 